\title{
EFFICACY OF DUAL GOLD (S-METOLACHLOR) ON WEED BIOMASS, AND ON THE GROWTH AND YIELD COMPONENTS OF SUGAR BEET (Beta Vulgaris L.) CV. CALIFORNIA-KWS
}

Imran Khan ${ }^{1 *}$, Muhammad Iqbal ${ }^{1}$, Malik Muhammad Hashim ${ }^{2}$, Muhammad Saleem Jilani ${ }^{1}$, Mohammad Safdar Baloch ${ }^{3}$, Muhammad Sohail Khan ${ }^{1}$, Asif Latif ${ }^{1}$, Muhammad Amjad Nadim $^{3}$, Muhammad Mamoon-ur-Rashid ${ }^{4}$

DOI: https://doi.org/10.28941/pjwsr.v27i4.985

\begin{abstract}
Weed infestation is a major problem and matter of concern as it reduces yield as well as quality of many crops including sugar beet. Manual weeding is very tedious, costly, time consuming and most probably non-availability of trained and skillful labor is another issue. Keeping in view these facts, an experiment was performed to evaluate the efficacy of dual gold on the weed biomass $\left(\mathrm{g} \mathrm{m}^{-2}\right)$ and on the growth and yield components of sugar beet (Beta vulgaris L.) CV. California-KWS during 2013-14 and 2014-15. The study was performed using RCBD having five treatments and three replications. The treatments included different application times (pre-emergence application and application after 15, 30 and 45 days after emergence) of dual gold (Smetolachlor) and a control (weedy check). Data were recorded on fresh and dry weed biomasses $\left(\mathrm{g} \mathrm{m}^{-2}\right)$, number of leaves plant ${ }^{-1}$, leaf area plant ${ }^{-1}\left(\mathrm{~cm}^{2}\right)$, leaf and root weights plant ${ }^{-1}(\mathrm{~g})$, sucrose $(\%)$, TSS $(\%)$, root and sugar yields ( $\left.\mathrm{t} \mathrm{ha}^{-1}\right)$. The results showed significant variation among the treatments for all parameters during both years of study. Among the treatments, the dual gold (S-metolachlor) applied as preemergence reduced weed fresh and dry biomasses $\left(\mathrm{g} \mathrm{m}^{-2}\right)$ and also enhanced number of leaves plant ${ }^{-1}$, leaf area $\left(\mathrm{cm}^{2}\right)$, leaf and root weight plant ${ }^{-1}$, sucrose (\%), TSS (\%), root and sugar yields ( $\mathrm{t} \mathrm{ha}^{-1}$ ) during both years. Hence, it is concluded that dual gold (Smetolachlor) applied as pre-emergence is best for eradicating weeds at early stages of growth and hence improving yield and quality of sugar beet under Dera Ismail Khan conditions.
\end{abstract}

Keywords: Quality, Sugar beet, S-metolachlor, Yield

Citation: Khan, I.; M. Iqbal; M.M. Hashim; M.S. Jilani; M.S. Baloch; M.S. Khan; A. Latif; M.A. Nadim; M.M Rashid. 2021. Efficacy of Dual Gold (s-Metolachlor) on Weed Biomass and on the Growth and Yield Components of Sugar Beet (Beta vulgaris L.) cv. CaliforniaKWS. Pak. J. Weed Sci. Res., 27(4): 495-504.

\footnotetext{
${ }^{1}$ Department of Horticulture, Faculty of Agriculture, Gomal University, D. I. Khan

${ }^{2}$ Institute of Food Science and Nutrition, Gomal University, D. I. Khan

${ }^{3}$ Department of Agronomy, Faculty of Agriculture, Gomal University, D. I. Khan

${ }^{4}$ Department of Entomology, Faculty of Agriculture, Gomal University, D. I. Khan

*Corresponding author's email: imrankhan1441@gmail.com, imran.khan@gu.edu.pk
} 


\section{INTRODUCTION}

Sugar beet (Beta vulgaris L.) ranks second most important sugar crops after sugar cane with a production of $30 \%$ sugar annually all over the world. In the 2014-18 period, the world sugar beet production area averaged to $4,609,469$ ha, of which more than $68 \%$ were located in Europe. In this period, the average root yield in the world and Europe was close to $60 \mathrm{t} \mathrm{ha}^{-1}$ (FAOStat, $2020)$. Its roots contain $16-20 \%$ sucrose concentration (Paul et al., 2019). Sugar beet pulp is used to make high fiber dietary food additives while its syrup is used as a spread for sandwiches, cakes, (sweetening) sauces and desserts. In addition to beet root, the leaves are good source of carbohydrates, protein and vitamin $\mathrm{A}$. In addition, leaves are also beneficial as green manure (Katerji et al., 1997). Loam and clay loam soils are best for its cultivation. Sugar beet once established is tolerant to alkaline conditions. It is comparatively resistant to cold and drought (Ebrahimian et al., 2009).

Agriculture sector has an important role in improving the economic growth of Pakistan. However, the production of agricultural crops is far below in most of the developing nations including Pakistan (Mazhar et al., 2021). The contribution of agriculture sector to GDP is $19.3 \%$, although there is a lot of potential in this sector to enhance its share in GDP with the use of modern agricultural techniques and improved crop productivity (GOP, 2020).

In Pakistan, during 2018-19, sugar beet was cultivated on an area of 5627 hectares with a production of 363733 tons, while in Khyber Pakhtunkhwa, it was cultivated on an area of 1014 hectares with an annual production of 38620 tons (FVC, 2020). It is a good alternative sugar crop in the region. Despite numerous advantages over sugarcane, it is still restricted to Khyber Pakhtunkhwa only but the area under this crop is continuously on decline. Moreover, due to lack of technical knowledge its average yield is also reducing. In Pakistan, the availability of agricultural water is unceasingly declining due to which sugarcane cultivation has become a difficult task in some areas. Under such circumstances, the sugar beet is a suitable solution as it has the potential of giving two-time higher sugar yield per hectare as compared to sugarcane in a short period of 5-6 months. Now only two sugar beet crushing mills (Premier in Charsadda and Al-Moiz in D. I. Khan) are working in Khyber Pakhtunkhwa, while the other two have stopped operation due to shortage of raw material. In a short time, sugar beet provides more financial returns per acre than sugar cane (Iqbal and Saleem, 2015). In Khyber Pakhtunkhwa province, sugar beet is commercially grown mostly in areas of Peshawar, Charsadda, Mardan, and the whole District of D. I. Khan. Generally, its sowing is done in October to November and harvested in April to May. Harvesting cannot be delayed from April to the 1st week of May, as a sudden boost in temperature reduces yield and recovery due to root rot causing huge economic losses to the growers. Despite the suitability of agro-climatic conditions, the productivity of sugar beet in Pakistan is far below as compared to its potential. Inadequate supply of essential nutrients, moisture stress at critical growth stages, conventional agronomic practices and abundant weeds are the key factors responsible for low yield.

Weeds reduce production of crops by competing with crops for water, light, nutrients, moisture and space (Anonymous, 2005). Chaudhry et al. (2008) reported that when weeds are allowed to grow beyond 50 days after sowing of crop, they reduce grain yield and yield attributes substantially. Work on weed distribution and their management techniques have extensively been done across the world (Boz et al., 2000, Pysek et al., 2005; Khan et al., 2012; Jawad et al., 2013; Khaliq et al., 2013). Increase in weed density, biomass and species, increases high yield losses (Blackshaw et al., 2002). Weeds are one of the biggest limiting factors in crop production, as a result of structural and financial problem, it deteriorates cultural condition of the soil (Farkas, 2006). The chemical weed control in sugar beet not 
only better, but also more economical than hand weeding and hoeing. sMetolachlor is chloroacetamide a preplant weed control herbicide but recently, it was also used as post-plant in sugar beet after the crop has two true leaves (Anonymous 2005a, b) but both can cause sugar beet injury under certain conditions in pre and post application (Bollman et al., 2008). Use of herbicides is more economical as hand weeding is very costly and have damaging effect on beet crop. Sugar beet crop cultivated in field needed both pre- and post-emergence application of herbicide depending on weed infestation of the field and cultural practices (Mobarak, 2013).

Various types of herbicides are available in the market but their proper and judicious application is still lacking and it needs to be improved. Keeping in view the above-mentioned facts obtained from the past literature, this research was designed to look at the efficacy of dual gold (s-Metolachlor) on weed biomass $\left(\mathrm{g}^{-2}\right)$ and on the growth and yield components of sugar beet (Beta vulgaris L.) under Dera Ismail Khan conditions.

\section{MATERIALS AND METHODS}

A field experiments was performed at Horticulture research area, Faculty of
Agriculture, Gomal University D. I. Khan during session 2013-14 and 2014-15. The study was performed in RCB Design having five treatments and replicated thrice. The field was ploughed to a fine tilth before planting and plotting was made according to the experimental treatment. The plot size was $4 \mathrm{~m} \times 3 \mathrm{~m}$ $\left(12 \mathrm{~m}^{2}\right)$ with 50 and $20 \mathrm{~cm}$ inter and intra-row spacing, respectively. Spacing of 0.6 and $1 \mathrm{~m}$ were allocated between plots and blocks, respectively. The hybrid Cv. California-KWS seeds were obtained from Al-Moiz Sugar Mills, D. I. Khan and were planted on ridges on $15^{\text {th }}$ October and $17^{\text {th }}$ October, respectively. Dual gold 960EC (S-metolachlor) @ 2 L ha $^{-1}$ was used a solo herbicide. Treatments included pre-emergence application and application at 15, 30 and 45 days after emergence and a weedy check. Plots were irrigated immediately after planting and then fortnightly. Recommended doses of N.P.K fertilizers were given at the rate of 120,100 and $75 \mathrm{~kg} \mathrm{ha}^{-1}$, respectively (Ahmad et al., 2010). Two third of $N$, all $P$ and $K$ were applied before ridge making while rest of $\mathrm{N}$ was applied before earthen up of ridges. Urea, TSP and SOP were the source of NPK.

Table. 1. Description of herbicide used for the experiment

\begin{tabular}{|l|l|l|}
\hline Common name & Trade name & Chemical name \\
\hline S-metolachlor & Dual Gold 960 EC & $\begin{array}{l}\text { [2-chloro-6-ethyl-N-(2-methoxy- } \\
\text { 1-methylethyl) acet-o-toluidide }\end{array}$ \\
\hline
\end{tabular}

\section{Soil analysis}

Soil of the experimental plot was clay loam in texture. Soil physico-chemical characteristics were determined before sowing. The detail is given in Table 2 .

Table 2: $\quad$ Soil Physicochemical properties of the experimental area.

\begin{tabular}{lll} 
Soil analysis & $\mathbf{2 0 1 3}$ & $\mathbf{2 0 1 4}$ \\
\hline EC $\left(\mathrm{ds} \mathrm{m}^{-1}\right)$ & 4.07 & 4.06 \\
$\mathrm{pH}$ & 7.6 & 7.7 \\
Texture & Clay loam & Clay loam \\
Saturation $(\%)$ & 56 & 55 \\
Organic matter $(\%)$ & 0.62 & 0.63 \\
N (\%) & 0.04 & 0.06 \\
P ppm & 8.00 & 8.02 \\
K ppm & 250 & 256 \\
\hline
\end{tabular}

Source. Soil Chemistry Laboratory Agriculture Research Institute, Ratta Kulachi, D. I. Khan (KPK), Pakistan. 


\section{Weather}

Monthly averaged meteorological data i.e. mean temperature; total rainfall and relative humidity of the trial (from sowing to harvesting) are shown in Fig. 1.

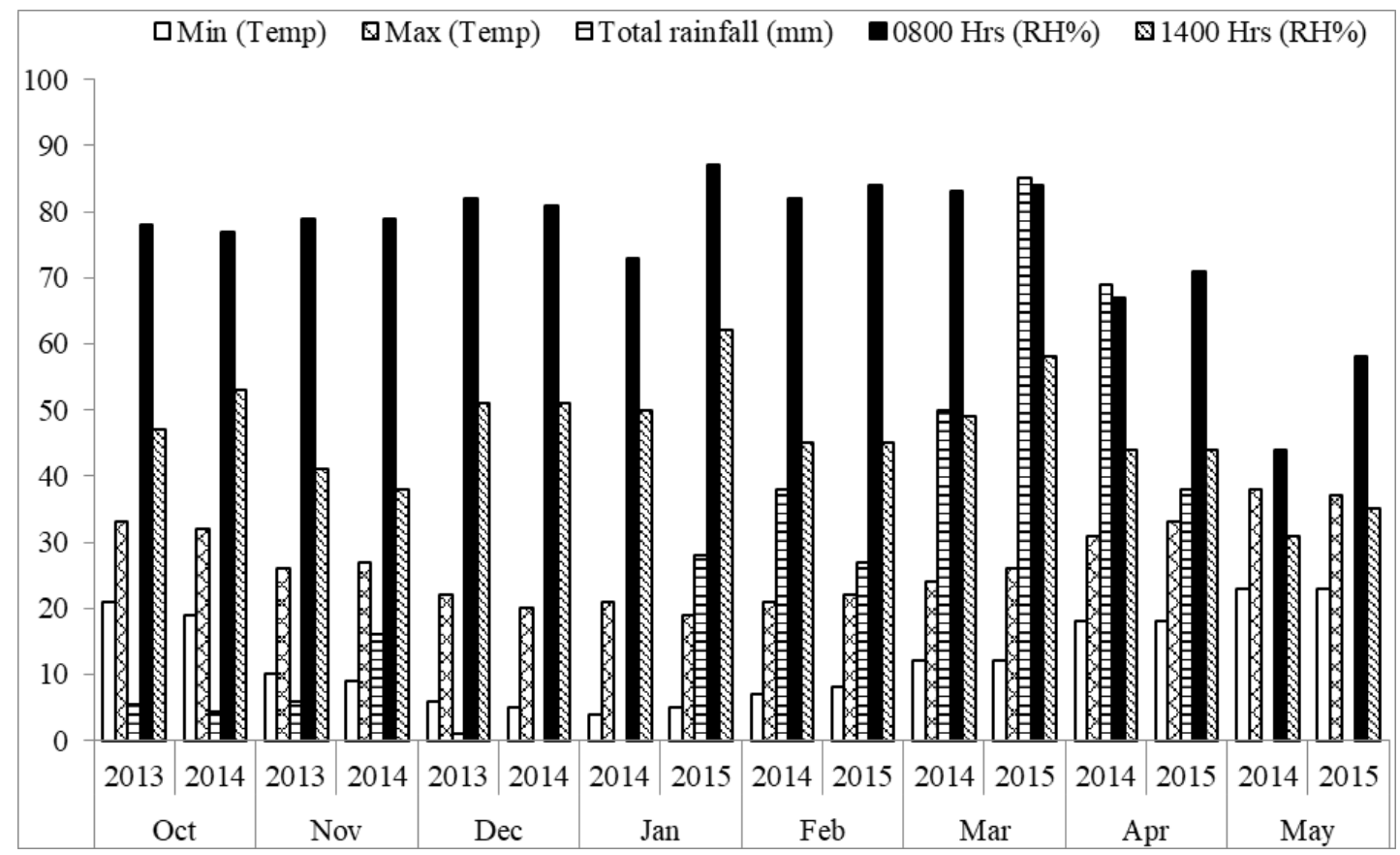

Fig. 1 Meteorological data of spot from October to May (2013-14 and 2014-15)

\section{Data recorded}

Data on the following parameters were recorded:

Fresh weed biomass $\left(\mathrm{g} \mathrm{m}^{-2}\right)$ : It was measured by taking weeds in one square meter area of each treatment were removed, weighed and averaged.

Dry weed biomass $\left(\mathrm{g} \mathrm{m}^{-2}\right)$ : Weeds from $1 \mathrm{~m}^{2}$ were cut at the ground level and weighed then sun dried for 72 hours to record the dry weight.

Number of leaves plant $^{-1}$ : Ten plants from each replication were taken randomly to count leaves and mean was calculated.

Leaf area plant ${ }^{-1}\left(\mathrm{~cm}^{2}\right)$ was determined as per Ahmad et al. (2010.

Leaf and root weight plant ${ }^{-1}$ : Ten plants were taken at random from each replication at maturity to determine leaf and root weights by a digital scale (0.01 $\mathrm{g}$ precision) and mean was calculated.

Total soluble solids\% (TSS\%) was assessed using hand refractometer as per A.O.A.C (2005).
Sucrose (\%): Sucrose \% was determined by Lane and Eynon method as described in A.O.A.C (2005).

Root Yield (t ha-1): At harvest, roots were separated, cleaned and weighed in kilogram $(\mathrm{kg})$, then were converted to estimate root yield ton ha- ${ }^{-1}$ as below:

$$
\begin{aligned}
& \text { Root yield (ton ha }-1) \\
& =\frac{\text { Root yield }(\mathrm{kg}) \times 10000}{1000 \times \text { Plot size }}
\end{aligned}
$$

Sugar yield $\left(\mathrm{t} \mathrm{ha}^{-1}\right)$ : It was calculated by using following equation

$$
\begin{aligned}
& \text { Sugar yield }=\frac{\text { Root yield } \times \text { sucrose } \%}{100} \\
& \text { Statistical Analysis }
\end{aligned}
$$

\section{Statistical Analysis}

All data was subjected to analysis of variance (ANOVA) as stated by Steel and Torrie (1997) using Statistics 8.1 software. Mean values of treatments were compared by using Fisher's protected LSD test and judged at $P \leq$ 0.05 levels. 


\section{RESULTS AND DISCUSSION} Weeds flora

The following weeds were present in sugar beet field (Table 3 ).

Table 3. Weeds found in sugar beet crop during 2013-14 and 2014-15.

\begin{tabular}{|l|l|}
\hline English Name & Botanical Name \\
\hline Lamb's quarter & Chenopodium album L. \\
\hline White sweet clover & Melilotus alba L. \\
\hline Wild oat & Avena fatua L. \\
\hline Little canarygrass & Phalaris minor Retz. \\
\hline Purple nutsedge & Cyprus rotundus L. \\
\hline Bermuda grass & Cynodon dictylon L. \\
\hline Field bind weed & Convolvulus arvensis L. \\
\hline Indian clover & Melilotus indica L. \\
\hline Dock broad Leaf & Rumex dentatus L. \\
\hline Wild onion & Asphodelius tenuifolius L. \\
\hline Libbein & Euphorbia helioscopia L. \\
\hline
\end{tabular}

\section{Fresh weed biomass $\left(\mathrm{g} \mathrm{m}^{-2}\right)$}

Different application times of Dual gold (S-metolachlor) affected $(P \leq 0.05)$ fresh weed biomass $\left(\mathrm{g} \mathrm{m}^{-2}\right)$ during 2013-14 and 2014-15 (Table 4). Maximum fresh weed biomass (1318.3 \& $1185.0 \mathrm{~g} \mathrm{~m}^{-2}$ ) was found in T1 followed by T5 $\left(1267.7 \& 1170.0 \mathrm{~g} \mathrm{~m}^{-2}\right), \mathrm{T} 4$ (1206.3 \& $1144.0 \mathrm{~g} \mathrm{~m}^{-2}$ ) and T3 (1135.0 \& $1131.7 \mathrm{~g} \mathrm{~m}^{-2}$ ) while minimum fresh weed biomass (496.7 \& $491.3 \mathrm{~g} \mathrm{~m}^{-2}$ ) was registered in T2 during both years. Bezuidenhout and Reinhardt (2002), Khan et al. (2003), Jacob (2003), Hassan et al. (2010), Ali et al (2017) and Chang et al. (2021) reported similar results in various crops.

\section{Dry weed biomass $\left(\mathrm{g} \mathrm{m}^{-2}\right)$}

Dry weed biomass $\left(\mathrm{g} \mathrm{m}^{-2}\right)$ was affected $(P \leq 0.05)$ due to different Dual gold (Smetolachlor) application times during 2013-14 and 2014-15 (Table 4). The lowest dry weed biomass (152.67 \& $147.67 \mathrm{~g} \mathrm{~m}^{-2}$ ) was recorded in T2 and the highest dry weed biomass (430.0 \& $408.67 \mathrm{~g} \mathrm{~m}^{-2}$ ) was found in T1 followed by T5 (412.33 \& $\left.399.67 \mathrm{~g} \mathrm{~m}^{-2}\right), \mathrm{T} 4$ (395.0 \& $385.33 \mathrm{~g} \mathrm{~m}^{-2}$ ) and T3 (373.67 \& $359.33 \mathrm{~g} \mathrm{~m}^{-2}$ ) during both years. These results corroborate the findings of Abdullah et al. (2008) and Saleem et al. (2015) who recorded minimum dry biomass in the treatment where Dual gold was applied as pre-emergence. Chang et al. (2021) reported similar results in barley.

\section{Number of leaves plant ${ }^{-1}$}

The number of leaves plant $^{-1}$ improved $(P \leq 0.05)$ due to Dual gold (Smetolachlor) application times during 2013-14 and 2014-15 (Table 4). The maximum leaf count (38.53 \& 43.47) was recorded in T2 followed by T3 (37.73 \& 42.70), T4 (36.53 \& 40.53) and T5 (36.17 \& 39.47) while lowest (33.87 \& 38.13) was noticed in $\mathrm{T} 1$ during both years. It might be due to reduced competition between weeds and the sugar beet plants resulting in increased water absorption and fertilizers from the soil, ultimately enhance vegetative growth. The results agree with Jursik et al. (2008), Baloch et al. (2013), Mobarak (2013) and Hameed et al. (2017).

\section{Leaf area plant ${ }^{-1}\left(\mathrm{~cm}^{2}\right)$}

Leaf area plant ${ }^{-1}\left(\mathrm{~cm}^{2}\right)$ differed $(P \leq$ 0.05 ) due to Dual gold (S-metolachlor) application times during 2013-14 and 2014-15 (Table 4). Significantly maximum leaf area (486.03 \& 486.74 $\mathrm{cm}^{2}$ ) was observed in T2 followed by T3 (476.42 \& $\left.479.06 \mathrm{~cm}^{2}\right)$, T4 (465.72 \& $475.99 \mathrm{~cm}^{2}$ ) and T5 (445.99 \& 468.42 $\mathrm{cm}^{2}$ ) and the lowest leaf area (424.02 \& $434.42 \mathrm{~cm}^{2}$ ) was observed in T1 during both years. Leaf area has a massive role in the canopy closure of the crop and restricting the weeds, hence yield will be directly affected by its size and indirectly weeds also (Gregory et al., 1994; Roggenkamp, 1997). The findings might 
be due to superior leaf number and size in pre-emergence application due to minimum competition between beets and weeds for nutrition. The results are in line with Hassan et al. (2010) and Khan (2002) who reported least leaf area of maize in weedy check.

Leaf weight plant $^{-1}(\mathrm{~g})$

Leaf weight plant $^{-1}(\mathrm{~g})$ differed $(P \leq$ 0.05 ) due to Dual gold (S-metolachlor) application times (Table 4). Significantly maximum leaf weight plant $^{-1}$ (386.90 \& $385.44 \mathrm{~g}$ ) was observed in T2 followed by T3 (384.61 \& $384.33 \mathrm{~g})$, T4 (382.46 $\& 383.80 \mathrm{~g})$ and T5 (377.06 \& $382.55 \mathrm{~g})$ while lowest leaf weight plant ${ }^{-1}$ (360.32 \& $380.62 \mathrm{~g}$ ) was observed in T1 during both years. The result might be due to better leaf growth and size with preemergence application of S-metolachlor due to better weed control, lowering the competition between crop-weed for nutrition. The results agree with Jursik et al. (2008), Rasha (2010) and Mobarak (2013).

Table. 4 Effect of dual gold (S-metolachlor) on Fresh and Dry weed biomasses $\left(\mathrm{g} \mathrm{m}^{-2}\right)$, Number of leaves plant ${ }^{-1}$, Leaf area plant ${ }^{-1}\left(\mathrm{~cm}^{2}\right)$, Leaf weight plant ${ }^{-1}(\mathrm{~g})$

\begin{tabular}{|c|c|c|c|c|c|}
\hline \multicolumn{6}{|c|}{ Year 2013-14 } \\
\hline Treatments & $\begin{array}{l}\text { Fresh weed } \\
\text { biomass } \\
\left(\mathrm{g} \mathrm{m}^{-2}\right)\end{array}$ & $\begin{array}{c}\text { Dry weed } \\
\text { biomass } \\
\left(\mathrm{g} \mathrm{m}^{-2}\right)\end{array}$ & $\begin{array}{l}\text { Number of } \\
\text { leaves } \\
\text { plant }^{-1}\end{array}$ & $\begin{array}{l}\text { Leaf area } \\
\text { plant } \\
\left(\mathrm{cm}^{\mathbf{2}}\right)\end{array}$ & $\begin{array}{l}\text { Leaf } \\
\text { weight } \\
\text { plant }^{-1}(g)\end{array}$ \\
\hline$T_{1}$ & $1318.3 \mathrm{a}$ & $430.00 \mathrm{a}$ & $33.87 \mathrm{c}$ & $424.02 \mathrm{e}$ & $360.32 \mathrm{c}$ \\
\hline $\mathbf{T}_{2}$ & $496.7 \mathrm{e}$ & $152.67 \mathrm{e}$ & $38.53 \mathrm{a}$ & $486.03 \mathrm{a}$ & $386.90 \mathrm{a}$ \\
\hline $\mathbf{T}_{3}$ & $1135.0 \mathrm{~d}$ & $373.67 \mathrm{~d}$ & $37.73 a$ & $476.42 \mathrm{~b}$ & $384.61 \mathrm{ab}$ \\
\hline $\mathbf{T}_{4}$ & $1206.3 \mathrm{c}$ & $395.00 \mathrm{c}$ & $36.53 \mathrm{~b}$ & $465.72 \mathrm{c}$ & $382.46 a b$ \\
\hline $\mathbf{T}_{5}$ & $1267.7 \mathrm{~b}$ & $412.33 \mathrm{~b}$ & $36.17 \mathrm{~b}$ & $445.99 \mathrm{~d}$ & $377.06 \mathrm{~b}$ \\
\hline LSD & 37.691 & 11.868 & 1.0330 & 2.6426 & 8.3949 \\
\hline \multicolumn{6}{|c|}{ Year 2014-15 } \\
\hline$\overline{\mathbf{T}_{1}}$ & $1185.0 \mathrm{a}$ & $408.67 \mathrm{a}$ & $38.13 \mathrm{e}$ & $434.42 \mathrm{e}$ & $380.62 \mathrm{e}$ \\
\hline $\mathbf{T}_{2}$ & $491.3 \mathrm{c}$ & $147.67 \mathrm{~d}$ & $43.47 \mathrm{a}$ & $486.74 \mathrm{a}$ & $385.44 \mathrm{a}$ \\
\hline $\mathbf{T}_{3}$ & $1131.7 \mathrm{~b}$ & $359.33 \mathrm{c}$ & $42.70 \mathrm{~b}$ & $479.06 \mathrm{~b}$ & $384.33 \mathrm{~b}$ \\
\hline $\mathbf{T}_{4}$ & $1144.0 \mathrm{~b}$ & $385.33 \mathrm{~b}$ & $40.53 \mathrm{c}$ & $475.99 \mathrm{c}$ & $383.80 \mathrm{c}$ \\
\hline $\mathbf{T}_{5}$ & $1170.0 \mathrm{a}$ & $399.67 \mathrm{a}$ & $39.47 \mathrm{~d}$ & $468.42 \mathrm{~d}$ & $382.55 \mathrm{~d}$ \\
\hline LSD & 20.003 & 9.3954 & 0.5064 & 0.8077 & 0.1635 \\
\hline
\end{tabular}

Means sharing similar letters do not differ $(P \leq 0.05)$

$\mathrm{T} 1=$ Control (weedy check), T2=Pre-emergence, T3=15 days after emergence, T4=30 days after emergence, $\mathrm{T} 5=45$ days after emergence.

\section{Root weight plant ${ }^{-1}(\mathrm{~g})$}

Dual gold (S-metolachlor) application times affected $(P \leq 0.05)$ root weight plant $^{-1}$ (g) significantly during 2013-14 and 2014-15 (Table 5). Highest root weight plant $^{-1}$ (1276.8 \& $\left.1298.4 \mathrm{~g}\right)$ was observed in T2 followed by T3 (1267.5 \& $1284.4 \mathrm{~g})$, T4 (1259.8 \& $1283.8 \mathrm{~g})$ and T5 (1236.4 \& $1282.8 \mathrm{~g}$ ) while minimum root weight plant ${ }^{-1}$ (1158.6 \& $1169.8 \mathrm{~g}$ ) was observed in T1 during both years. It might be due to the efficacy of Smetolachlor controlling weeds at early stage of the growth resulting higher element accumulation in roots. Findings are in alignment with Salehi et al. (2006), Hassan et al. (2010), Mobarak (2013) and Merga and Alemu (2019).

\section{Sucrose (\%)}

Weed treatments affected $(P \leq 0.05)$ sucrose contents during both years as illustrated in Table 5. The highest sucrose\% (16.32 \& 16.47) was found in T2 followed by T3 (16.23 \& 16.32), T4 (16.11 \& 16.28) and T5 (15.99 \& 16.23) and minimum sucrose $\%(15.90 \& 15.87)$ was registered in T1 during both years. The result might be due to quality of crop produced under weeds free field. The results are in alignment with Fayed et al. (1999), Bosak and Mod (2000), Alaoui et al. (2003), Khan et al. (2006) and Mobarak (2013).

\section{Total Soluble Solids (TSS\%)}

Different weed treatments affected ( $P \leq$ 0.05 ) the TSS\% during both years as shown in Table 5 . The highest TSS\% 
(18.51 \& 18.73) was found in $\mathrm{T} 2$ followed by T3 (18.45 \& 18.65), T4 $(18.40 \& 18.60)$ and T5 (18.33 \& 18.47) while minimum TSS\% (18.27 \& 18.37) was registered in T1 during both years. The results agree with those reported by Bosak and Mod (2000), Khan et al. (2006) and Mobarak (2013).

\section{Root yield (t ha-1)}

Root yield (t ha-1) was affected ( $P \leq$ 0.05 ) due to different weed treatments during 2013-14 and 2014-15 (Table 5). Significantly highest root yield (62.27 \& $64.28 \mathrm{t} \mathrm{ha}^{-1}$ ) was found in T2 followed by T3 $\left(62.17 \& 63.62 \mathrm{t} \mathrm{ha}^{-1}\right)$, T4 $(60.97$ \& $\left.63.39 \mathrm{t} \mathrm{ha}^{-1}\right)$ and T5 (60.67 \& $62.70 \mathrm{t}$ $\mathrm{ha}^{-1}$ ) while minimum root yield ( $58.45 \&$ $60.45 \mathrm{t} \mathrm{ha}^{-1}$ ) was found in T1 during both years. The increase in root yield might be due to effective weed control in pre-emergence application as weeds are major hindrance in yield. The results agree with Khan et al. (2006), Salehi et al. (2006), Odero et al. (2010) and Mobarak (2013). Similarly, Khatam et al. (2013) reported significantly maximum grain yield in Dual Gold treatments. Chang et al. (2021) reported similar results in barley.

\section{Sugar yield (t ha-1)}

Data regarding sugar yield (t ha-1) show significant variation due to different weed treatments during 2013-14 and 2014-15 (Table 5). Significantly highest sugar yield (10.16 \& $10.59 \mathrm{t} \mathrm{ha}^{-1}$ ) was found in T2 followed by T3 (9.88 \& $\left.10.38 \mathrm{t} \mathrm{ha}^{-1}\right)$, T4 (9.82 \& $\left.10.32 \mathrm{t} \mathrm{ha}^{-1}\right)$ and T5 (9.70 \& $10.18 \mathrm{t} \mathrm{ha}^{-1}$ ) while minimum sugar yield $\left(9.30 \& 9.59 \mathrm{t} \mathrm{ha}^{-}\right.$ 1) was found in T1 during both years. The results might be due to improved root yield and decreased weed biomass $\left(\mathrm{g} \mathrm{m}^{-2}\right)$. The results agree with Alaoui et al. (2003), Khan et al. (2006), Salehi et al. (2006) and Mobarak (2013).

Table 5. Effect of dual gold (S-metolachlor) on Root weight plant ${ }^{-1}(\mathbf{g})$, Sucrose $\%$, TSS\%, Root and Sugar yield $\left(\mathrm{t} \mathrm{ha}^{-1}\right)$

\begin{tabular}{|c|c|c|c|c|c|}
\hline \multicolumn{6}{|c|}{ Year 2013-14 } \\
\hline Treatments & $\begin{array}{l}\text { Root weight } \\
\text { plant }^{-1}(\mathrm{~g})\end{array}$ & Sucrose\% & TSS\% & $\begin{array}{l}\text { Root yield } \\
\left(t \mathrm{ha}^{-1}\right)\end{array}$ & $\begin{array}{l}\text { Sugar yield } \\
\left(t \mathrm{ha}^{-1}\right)\end{array}$ \\
\hline $\mathbf{T}_{1}$ & $1158.6 \mathrm{~d}$ & $15.90 \mathrm{~d}$ & $18.27 \mathrm{c}$ & $58.45 \mathrm{~d}$ & $9.30 \mathrm{c}$ \\
\hline $\mathbf{T}_{2}$ & $1276.8 \mathrm{a}$ & $16.32 \mathrm{a}$ & $18.51 \mathrm{a}$ & $62.27 \mathrm{a}$ & $10.16 \mathrm{a}$ \\
\hline $\mathbf{T}_{3}$ & $1267.5 \mathrm{ab}$ & $16.23 \mathrm{ab}$ & $18.45 \mathrm{ab}$ & $62.17 \mathrm{a}$ & $9.88 \mathrm{~b}$ \\
\hline $\mathbf{T}_{4}$ & $1259.8 \mathrm{~b}$ & $16.11 \mathrm{bc}$ & $18.40 \mathrm{~b}$ & $60.97 b$ & $9.82 \mathrm{~b}$ \\
\hline$T_{5}$ & $1236.4 \mathrm{c}$ & $15.99 \mathrm{~cd}$ & $18.33 \mathrm{c}$ & $60.67 c$ & $9.70 \mathrm{~b}$ \\
\hline LSD & 15.000 & 0.1250 & 0.0654 & 0.1644 & 0.2794 \\
\hline \multicolumn{6}{|c|}{ Year 2014-15 } \\
\hline $\mathbf{T}_{1}$ & $1169.8 \mathrm{e}$ & $15.87 \mathrm{~d}$ & $18.37 \mathrm{e}$ & $60.45 \mathrm{e}$ & $9.59 \mathrm{e}$ \\
\hline $\mathbf{T}_{2}$ & $1298.4 \mathrm{a}$ & $16.47 \mathrm{a}$ & $18.73 \mathrm{a}$ & $64.28 \mathrm{a}$ & $10.59 \mathrm{a}$ \\
\hline $\mathbf{T}_{3}$ & $1284.4 \mathrm{~b}$ & $16.32 \mathrm{~b}$ & $18.65 \mathrm{~b}$ & $63.62 \mathrm{~b}$ & $10.38 \mathrm{~b}$ \\
\hline $\mathbf{T}_{4}$ & $1283.8 \mathrm{c}$ & $16.28 \mathrm{bc}$ & $18.60 \mathrm{c}$ & $63.39 \mathrm{c}$ & $10.32 \mathrm{c}$ \\
\hline $\mathbf{T}_{5}$ & $1282.8 \mathrm{~d}$ & $16.23 \mathrm{c}$ & $18.47 \mathrm{~d}$ & $62.70 \mathrm{~d}$ & $10.18 \mathrm{~d}$ \\
\hline LSD & 0.2493 & 0.0740 & 0.0257 & 0.1003 & 0.0527 \\
\hline
\end{tabular}

Means sharing similar letters do not differ $(P \leq 0.05)$

$\mathrm{T} 1=$ Control (weedy check), T2=Pre-emergence, $\mathrm{T} 3=15$ days after emergence, $\mathrm{T} 4=30$ days after emergence, $\mathrm{T} 5=45$ days after emergence

\section{CONCLUSION AND RECOMMENDATIONS}

The study has revealed that dual gold (S-metolachlor) suppressed weed growth in sugar beet field which in turn improved root and sugar yield. As a result, it can be deduced that applying dual gold as a pre-emergence is the most effective for controlling of weed and improving yield and quality of sugar beet. However, further research work needs to explore more weed management strategies to control weeds and to enhance the yield of sugar beet crop in the area. 


\section{REFERENCES CITED}

AOAC. 2005. Association of Agricultural Chemistry. Official Methods of Analysis.14 Association of Official Agriculture Chemist, Washington D.C U.S.A. PP.777-1060.

Abdullah, G.H., I.A. Khan., S.A. Khan and $H$. Ali. 2008. Impact of planting methods and herbicides on weed biomass and some agronomic traits of maize. Pak. J. Weed Sci. Res., 14(3-4): 121130.

Ahmad, Z., P. Shah, K.M. Kakar, H. ElSharkawi, P.B. Gama, E.A. Khan and S. Yamamoto. 2010. Sugar beet (Beta vulgaris L.) response to different planting methods and row geometries II: Effect on plant growth and quality. J. Food, Agric. Environ., 8(2): 785-791.

Ali, N., M, Ashiq and H. Ameer. 2017. Efficacy of different herbicides for weed control in garlic (Allium sativum L.). J. Environ. Agric. Sci., 12: 19-24.

Alaoui, B.S., D.L. Wyseand and A.G. Dexter. 2003. Weed interference and control in sugar beet (Beta vulgaris L.) in the Gharb region of Morocco. J. Sug. Beet Res., 40 (4): 229-249.

Anonymous. 2005a. OutlookHherbicide label. Research Triangle Park, NC: BASF Corporation. Pp. 9.

Anonymous. 2005b. Dual Magnum Hherbicide label. Greensboro, NC: Syngenta Crop Protection, Inc. pp. 16.

Anonymous.2005. Punjab Department of Statistics. Bureau of Statistics, Govt. of Punjab, Lahore.

Baloch, A.A., M. Saqib, M.S. Baloch, M. Sadiq and M. Zubair. 2013. Efficacy of different weedicides as affected by their mode of application in wheat crop. Pak. J. Weed Sci. Res., 19(4): 419-425.

Bezuidenhout, S.R and C.F. Reinhardt. 2002. Using cover crops (maize) to suppress weed growth. Combined Congress 2009, South African Soc. Crop Prod. and South African Weed Sci. Soc.

Blackshaw, R.E., D. Lemerle, R. Mailer and K.R. Young. 2002. Influence of wild radish on yield and quality of canola. Weed Sci., 50: 334349.

Bollman, S.L., C.L. Sprague and D. Penner. 2008. Physiological basis for tolerance of sugarbeet varieties to s-Metolachlor and Dimethenamid-P. Weed Sci., 56: 18-25.

Bosak, P and S. Mod. 2000. Influence of different weed species on sugar beet yield. Hungary. Novenytermeles, 49(5): 571-580.

Boz, O., M.N. Dogan and S. Dura. 2000. A survey study on distribution and density of weeds species occurring in wheat fields of Denizli Province. Turkiyeherboloji Dergisi., 3: 37-52.

Chang, M.S. M.N. Kandhro, Z.A. Abbasi, J.K. Sootaher, K.A. Buriro, Z. Channa, N. Mangrio. 2021. Comparative efficacy of purple nutsedge allelopathy and other methods on weed management in bBarley (Hordeum Vulgare L.). Pak. J. Weed Sci. Res., 27 (2): 127-137.

Chaudhry, S., M. Hussain, M.A. Ali and J. Iqbal. 2008. Effect of duration of weed competition period on yield and yield components of wheat. Pak. J. Agric. Res., 46(1): 47-53.

Chou, J.C. 1966. Recent development of chemical weed control at Monochro. Taiwan Sug. J., 13 (4): 13-17.

Ebrahimian, H.R., S.Y. Sadeghian, M.R. Jahadakbar and Z. Abbasi. 2009. Study of adaptability and stability of sugar beet monogerm cultivars in different locations of Iran. Bulgarian J. Agric. Sci., 24: 1-13.

Farkas. 2006. Soil management and tillage possibilities in weed control. Herbologia, (7: 9-23.

FAOStat. 2020. Food and Agriculture Organization of the United Nations. http://www.fao.org/ faostat/en/\#data/QC (accesed on 20 April 2020).

FVC. 2020. Fruit vegetable \& condiments statistics of Pakistan. Economic wing, ministry of national food security \& research economic wing, Islamabad, 2018-19, p:1120. 
Fayed, M.T.B., I.H. El-Geddawy and M.M. El-Zeny. 1999. Influence of weed interference on growth, yield and quality of sugar beet. Egypt. J. Agric. Res., 77(3): 1239-1249.

Garracho, S.S. and G.P. Lirazen. 1971. Herbicide application at biecum. Sug. News., 7: 78-79.

GOP. 2020. Agricultural Statistics of Pakistan. Government of Pakistan. Ministry of Food, Agriculture and Livestock, Economic Wing, Islamabad. pp. 21.

Gregory, J.R.K., C.M. Stephen, and A.R. Martin. 1994. Velvetleaf (Abutilon theophrasti) and green foxtail (Setariaviridis) response to corn (Zea mays) hybrid. Weed Technol., 14(2): 304-311.

Hameed, R.A., S. Anjum, and M.N. Afzal. 2017. Effect of pre-emergence weedicides on weed control, yield and yield components in cotton on sandy loam soil. Int. J. Sci. Eng. Res., 8(2): 714-20.

Harvey, C. W, and J. V. Dutton. 1993. Root quality and processing in the sugar beet Crop. Springer, Dordrecht. pp. 571-617.

Hassan, G., S. Tanveer, N.U. Khan, and M. Munir. 2010. Integrating cultivars with reduced herbicide rates for weed management in maize. Pak. J. Bot., 42(3): 19231929.

Iqbal, M. A, and A. M. Saleem. 2015. Sugar beet potential to beat sugarcane as a sugar crop in Pakistan. Am.-Euras. J. Agric. Environ. Sci., 15(1): 36-44.

Jacob, W. 2003. Applying plant population ecology - Increasing the suppression of weeds by cereal crops. J. Agron., 2(4): 810.

Jawad, M., N. Khan, H. Khan, S. Zarin, Arifullah, M. Kashif, M. Adil, S. Rahman and R. Khan. 2013. Bioherbicidal potentials of wheat (Triticum aestivum L.) on some of its major weeds. Pak. J. Weed Sci. Res., 19(1): 79-87.

Jursik, M., J. Holec, J. Soukup, and V. Venclova. 2008. Competitive relationships between sugar beet and weeds in dependence on time of weed control. Plant, Soil Environ., 54(3): 108-116.

Katerji, N., J.W. Van Hoorn, A. Hamdy, M. Mastrorilli, and E.M. Karzel. 1997. Osmotic adjustment of sugar beets in response to soil salinity and its influence on stomatal conductance, growth and yield. Agric. Water Manage., 34(1): 57-69.

Khaliq, A., M.R. Gondal, A. Matloob, E. Ullah, S. Hussain and G. Murtaza. 2013. Chemical weed control in wheat under different rice residue management options. Pak. J. Weed Sci. Res., 19(1): 1-14.

Khan, M.A., K.B. Marwat, N. Khan, and I.A. Khan. 2003. Efficacy of different herbicides on the yield and yield components of maize. Asian J. Plant Sci., 2(3): 300304.

Khan, M.A. 2002. Efficacy of different herbicides on the yield and yield components of maize. M.Sc. Hons. Thesis, Department of Weed Science, NWFP Agric. Univ. Peshawar, Pak.

Khan, N., N.W. Khan, S.A. Khan, M.A. Khan, and K.B. Marwat. 2012. Combined effect of nitrogen fertilizers and herbicides upon maize production in Peshawar. J. Anim. Plant Sci., 22(2 Suppl.): 12-17.

Khan, S.N, and S. Minhas. 2006. Efficiency of different rates of dual gold herbicides for weed control in sugar beet. Pak. Sug. J. 11(5): 2-4.

Khatam, A., M.Z. Khan, K. Nawab, I.A. Mian, and W. Ahamad. 2013. Effect of various herbicides and manual control on yield, yield components and weeds of maize. Pak. J. Weed Sci. Res., 19(2): 209-216.

Mazhar, M.N., M. Arif, N. Akhtar, M. Shafiq and M. Yousaf. 2021. Impact of weeds management practices on wheat productivity. Pak. J. Weed Sci. Res., 27(2): 213-225.

Merga, B., and N. Alemu. 2019. Integrated weed management in chickpea (Cicer arietinum 
504 Imran Khan, Muhammad Iqbal et al. Efficacy of Dual Gold (S-Metolachlor) ....

L.). Cogent Food Agric., 5(1): 1620152.

Mobarak, A.O.M.M. 2013. Determination of critical period of weed competition with sugar beet (Beta vulgaris L.) and weed control. PhD thesis. Faculty of Agriculture Assiut University. pp. 1-147.

Odero, DC., A.O. Mesbah, S.D. Iller and A.R. Kniss. 2010. Wild buckwheat (Polygonum convolvulus) interference in sugar beet. Weed Tech., 24(1): 59-63.

Paul, S.K., R.A. Joni, M.A.R. Sarkar, M. Hossain and S.C. Paul. 2019. Performance of tropical sugar beet (Beta vulgaris L.) as influenced by year of harvesting. Arch. Agric. Environ. Sci., 4: 1926.

Pysek, P., M. Chytry, I. Tichy, and I. Knollova. 2005. Invasions by alien plants in the Czech Republic: a quantitative assessment across habitats. Presha, 77: 339-354.

Rasha, G.M. 2010. Improving the efficiency of some herbicides in weed control in sugar beet by some adjuvants. M.Sc. Thesis, Fac. Agric. Cairo Univ., Egypt.

Roggenkamp, G.J. 1997. Hybrid selection for reducing herbicide rates in corn. University of Nebraska Absts. pp. 2189.

Saleem, M.T., A. Tanveer, and T. Abbas. 2015. Weed control in forage maize with pre-emergence herbicides. Herbologia, 15(2): 69-77.

Salehi, F., H. Esfandiari and H.R. Mashhadi. 2006. Critical period of weed control in sugar beet in Sharecrop Region. Iran. J. Weed Sci., 2(2): 1-12.

Steel, R.G., J.H. Torrie, and D.A. Dickey. 1997. Principles and procedures of statistics: A biological approach. McGraw-Hill. pp. 352358. 